14 Juniper EF, Kline PA, Vanzielegham MA, Ramsdale EH, O'Byrne PM, Hargreave FE. Long term effect of budesonide on airway responsiveness and clinical asthma severity in inhaled steroid-dependent asthmatics. Eur Respir J 1990;3:1122-7.

15 Kerrebijn KF, Essen-Zandvliet EEM, Neijens HJ. Effect of long term treatment with inhaled corticosteroids and betalong term treatment with inhaled corticosteroids and betaagonists on the bronchial responsiveness in child
asthma. J Allergy Clin Immunol 1987;79:653-9.

16 Vatheven AS, Knox AJ, Wisniewski A, Tattersfield AE. Effect of budesonide on bronchial reactivity to histamine, exercise and eucapnic dry air hyperventilation in patients with asthma. Thorax 1991;46:811-6.

17 Littlewood JM, Johnson AW, Edwards PA, Littlewood AE.
Growth retardation in asthmatic children treated with beclomethasone dipropionate. Lancet 1988; i:115-6.

18 Koenig $\mathrm{P}$. The role of inhaled steroids in the treatment of asthma. Respir Med 1989;83(suppl):43-7.

19 Varsano I, Volovitz B, Malik H, Amir Y. Safety of 1-year of treatment with budesonide in young children with asthma. J Allergy Clin Immunol 1990;85:914-20.

20 Toogood JH, Jennings B, Baskerville J, Anderson J, Johansson SA. Dosing regimen of budesonide and occurrence of oropharyngeal complications.

21 Gleeson JGA, Price JF. Controlled trial of budesonide given by the nebuhaler in pre-school children with asthma. BMJ 1988;297:163-6.

\title{
Adventitia
}

\section{A sabbatical year in England}

At the end of August 1973 I arrived in London for a sabbatical year at the Brompton Hospital. Home was then the Veterans Administration Hospital, Cleveland, Ohio, and the Medical School of Case Western Reserve University. My choice of the Brompton was based on rumours, then afoot in the medical world of America, that the Brompton was the best pulmonary disease centre in the world. I was to form a clear opinion by the end of my adventure!

My official host was Kenneth Citron, who had invited me after a visit of his to the United States, and in his diffident way introduced me to the world of English clinical medicine. His ward round was carried out in low key, typical of Kenneth, and each patient's chart was reviewed in great detail. This was followed by a bedside visit to each patient by all of those participating. Thus was the form and substance of the ward round with each of the clinicians with whom I spent time. And quite a list it was: Margaret Turner-Warwick, Neville Oswald, Margaret Branthwaite, Philip Zorab, John Batten, and Jack Pepys. In addition, I had remarkably informative encounters with Guy Scadding, who had recently retired but was often present; Stuart Lennox, whose surgical consultations were pithy and spare of fluff; and George Simon, whose flare and talent for teaching radiology, and more, excited the registrars, house physicians, and one very impressed American visitor.

In the pathology laboratory I encountered KFW Hinson and Brian Heard, and in the research area were Lynn Reid, who had captivated me (along with most of the chest medicine community of the United States) several years before, and Donald Mitchell, a legend for his unique approaches to problems of granulomatous diseases, whose Yorkshire accent was difficult to fathom for these inexperienced American ears. About each of these personalities I have bright and shining recollections that must remain unspoken owing to constraints of space.

The physical plant was, to an American of the time, shabby beyond belief. On close inspection, however, I discovered that the place was spotless, and wherever possible fresh paint had been applied and laboratories had been assembled in the relatively recently built Cardiothoracic Institute. As I browsed about the place I discovered that the "new wing" had been dedicated in the year that Koch announced the discovery of the tubercle bacillus, 1882 . The original hospital, still very functional, was opened in 1848. At that time London was more than 800 years old and Cleveland was still a collection of small Native American dwellings with few settlers in what was then called the Western Reserve of Connecticut. The tunnel connecting the two main buildings had a rise in the middle and a legend of having been traversed by pipes whose insulation had been crysotile until this was removed some few years before. I invariably used the tunnel with some trepidation, but the traffic of Fulham Road weighted the risk-benefit ratio in favour of the passageway.

My days were spent at the bedside with the above staff, browsing in the laboratories and the library, lunching in the pubs nearby or in the lounge in the institute, where white coats were left outside along with most things medical. I learned to solve the problems of the world with my hosts over biscuits, sandwiches, and juice, leaving the patients to their own devices for the half hour or so we all took. Morning coffee and afternoon tea were highest priority items. The biscuits, as always in London, were wonderful.

Who was the most important person I encountered during that sabbatical? None of the above. It was Cathy Ambrose, officially the secretary to the dean but admittedly the lynchpin of the entire operation. She saw to it that events came off on time and that the proper sherry was available when it was indicated. Her smile greeted me every day when I entered her office, where by chance I hung my hat. Cathy kept contact for many years after I left. I was not her only beneficiary. "No" was not in her vocabulary and she didn't even know how to spell "frown."

It was a fabulous year in which I learned (a) much about clinical medicine, (b) that English is different in England, and (c) that the Brompton Hospital was the best chest disease centre in the world!-GERARD L BAUM 